\title{
REVIEW
}

\section{Mechanisms of glucocorticoid-induced myopathy}

\author{
O Schakman, H Gilson and J P Thissen \\ Unité de Diabétologie et Nutrition, Faculté de Médecine, Université Catholique de Louvain, 54 Avenue Hippocrate, B-1200 Brussels, Belgium \\ (Correspondence should be addressed to J P Thissen; Email: jeanpaul.thissen@uclouvain.be)
}

\begin{abstract}
Glucocorticoid-induced muscle atrophy is characterized by fast-twitch or type II muscle fiber atrophy illustrated by decreased fiber cross-sectional area and reduced myofibrillar protein content. Muscle proteolysis, in particular through the ubiquitin- proteasome system (UPS), is considered to play a major role in the catabolic action of glucocorticoids. The stimulation by glucocorticoids of the UPS is mediated through the increased expression of several atrogenes ('genes involved in atrophy'), such as atrogin-1 and MuRF-1, two ubiquitin ligases involved in the targeting of protein to be degraded by the proteasome machinery. Glucocorticoids also exert an anti-anabolic action by blunting muscle protein synthesis. These changes in protein turnover may result from changes in the production of two growth factors which control muscle mass, namely IGF-I and myostatin respectively
\end{abstract}

anabolic and catabolic toward the skeletal muscle. The decreased production of IGF-I as well as the increased production of myostatin have been both demonstrated to contribute to the muscle atrophy caused by glucocorticoids. At the molecular level, IGF-I antagonizes the catabolic action of glucocorticoids by inhibiting, through the PI3-kinase/Akt pathway, the activity of the transcription factor FOXO, a major switch for the stimulation of several atrogenes. These recent progress in the understanding of the glucocorticoidinduced muscle atrophy should allow to define new therapies aiming to minimize this myopathy. Promising new therapeutic approaches for treating glucocorticoid-induced muscle atrophy are also presented in this review.

Journal of Endocrinology (2008) 197, 1-10

\section{Introduction}

The catabolic effects of glucocorticoids have been well known for many years. Either as drugs used to treat several medical conditions or as endocrine hormones released in response to many stress situations, glucocorticoids may cause skeletal muscle atrophy. The resulting weakness of peripheral and respiratory muscles may have major clinical implications such as loss of quality of life, fatigue, impaired wound healing, compromised lung function, and poor immune response. The purpose of this review is to describe the cellular and molecular mechanisms of the catabolic actions of glucocorticoids toward skeletal muscle. Better understanding of the mechanisms of the steroid myopathy should lead to the development of new therapeutic avenues to preserve muscle mass and function in patients exposed to high doses of glucocorticoids.

\section{Role of glucocorticoids in muscle atrophy of wasting conditions}

Many pathological conditions characterized by muscle atrophy (sepsis, cachexia, starvation, metabolic acidosis, severe

insulinopenia, etc.) are associated with increase in circulating glucocorticoids levels (Lecker et al. 1999), suggesting that these hormones could trigger the muscle atrophy observed in these situations. In the case of sepsis, cachexia, starvation, and severe insulinopenia, adrenalectomy or treatment with a glucocorticoid receptor antagonist (RU-486) attenuate muscle atrophy, indicating that glucocorticoids are in part responsible for this muscle loss. In addition to glucocorticoid excess, several other factors such as poor nutrition, cytokines and bed resting may contribute to muscle atrophy observed in these wasting conditions (Hasselgren 1999, Lecker et al. 1999). In contrast, glucocorticoids do not appear to be required for disuse atrophy (Tischler 1994), but may clearly exacerbate the deleterious effects of disuse on skeletal muscle mass (Fitts et al. 2007).

\section{Characterization of the glucocorticoid-induced muscle atrophy}

Skeletal muscle atrophy is characterized by a decrease in the size of the muscle fibers. Glucocorticoids have been shown to cause atrophy of fast-twitch or type II muscle fibers 
(particularly IIx and IIb) with less or no impact observed in type I fibers (Dekhuijzen et al. 1995, Fournier et al. 2003). Therefore, fast-twitch glycolytic muscles (i.e., tibialis anterior) are more susceptible than oxidative muscles (i.e., soleus) to glucocorticoid-induced muscle atrophy. The mechanism of such fiber specificity is not known.

\section{Mechanisms of glucocorticoid-induced muscle atrophy}

In skeletal muscle, glucocorticoids decrease the rate of protein synthesis and increase the rate of protein breakdown (Tomas et al. 1979, Goldberg et al. 1980, Lofberg et al. 2002) contributing to atrophy. The severity and the mechanism for the catabolic effect of glucocorticoids may differ with age. For example, glucocorticoids cause more severe atrophy in older rats compared with younger rats. Furthermore, glucocorticoid-induced muscle atrophy results mainly from increased protein breakdown in adult rats but mostly from depressed protein synthesis in the aged animals (Dardevet et al. 1998).

\section{Anti-anabolic action of glucocorticoids}

The inhibitory effect on protein synthesis results from different mechanisms. First, glucocorticoids inhibit the transport of amino acids into the muscle (Kostyo \& Redmond 1966), which could limit the protein synthesis. Secondly, glucocorticoids inhibit the stimulatory action of insulin, insulin-like growth factor-I (IGF-I), and amino acids (in particular leucine), on the phosphorylation of eIF4Ebinding protein 1 (4E-BP1) and the ribosomal protein S6 kinase 1 (S6K1), two factors that play a key role in the protein synthesis machinery by controlling the initiation step of mRNA translation (Shah et al. 2000a,b, Liu et al. 2001, 2004). Finally, there is also evidence that glucocorticoids cause muscle atrophy by inhibiting myogenesis through the downregulation of myogenin, a transcription factor mandatory for differentiation of satellite cells into muscle fibers (te Pas et al. 2000).

\section{Catabolic action of glucocorticoids}

The stimulatory effect of glucocorticoids on muscle proteolysis results from the activation of the major cellular proteolytic systems (Hasselgren 1999), namely the ubiquitinproteasome system (UPS), the lysosomal system (cathepsins), and the calcium-dependent system (calpains). The protein degradation caused by glucocorticoids affects mainly the myofibrillar proteins as illustrated by the increased excretion of 3-methyl histidine (Zamir et al. 1991, Tiao et al. 1996). To activate the protein degradation, glucocorticoids stimulate the expression of several components of the UPS either involved in the conjugation to ubiquitin of the protein to be degraded (ubiquitin; $14 \mathrm{kDa}$ (E2), a conjugating enzyme; atrogin-1 and MuRF-1, two muscle-specific (E3) ubiquitin ligases;
Bodine et al. 2001) or directly responsible for the protein degradation by the proteasome (several subunits of the $20 \mathrm{~S}$ proteasome; Mitch \& Goldberg 1996). This gene transcription activation is associated with an increased rate of protein ubiquitination and increased proteolytic activities of the proteasome itself (Combaret et al. 2005). Using blockers of the different proteolytic pathways, evidence was found that glucocorticoids stimulate not only the UPS-dependent proteolysis but also the calcium-dependent and lysosomal protein breakdown (Hasselgren 1999). The role of lysosomal system in the atrophic effect of glucocorticoids is also suggested by the increase in cathepsin L muscle expression in glucocorticoid-treated animals (Deval et al. 2001, Komamura et al. 2003, Sacheck et al. 2004). Because the proteasome does not degrade intact myofibrils, it is thought that actin and myosin need to be dissociated (probably by calpains) from the myofibrils before they can be degraded by the UPS (Hasselgren \& Fischer 2001). Finally, some in vivo data also suggest that caspase- 3 can be implicated in the myofibrillar proteins breakdown induced by glucocorticoids. Indeed, in glucocorticoid-dependent muscle wasting models, such as diabetes mellitus and chronic renal failure, caspase-3 activity in muscle is increased and inhibition of caspase- 3 by Ac-DEVD-CHO, a peptide inhibitor, suppresses the accelerated muscle proteolysis (Du et al. 2004). However, the role of glucocorticoids in the induction of caspase-3 activity in these models has not yet been explored.

\section{Signaling pathways involved in glucocorticoid- induced muscle atrophy}

\section{FOXO}

The muscle cell catabolism caused by glucocorticoids is thought to be mediated by the transcription factors FOXO. The role of these transcription factors in the glucocorticoidinduced muscle cell atrophy has been established by different observations. First, exposure of myotubes to glucocorticoids increases the FOXO gene expression, particularly -1 and -3 (Imae et al. 2003). Second, in vitro as well in vivo, FOXO overexpression causes muscle cell atrophy (Kamei et al. 2004, Sandri et al. 2004) together with activation of several genes characteristic of muscle cell atrophy or atrogenes such as atrogin-1, MuRF-1 and cathepsin L (Jagoe et al. 2002, Sandri et al. 2004). Finally, overexpression of a dominant negative form of $\mathrm{FOXO}-3$ a prevents muscle cell atrophy together with atrogin-1 induction caused by glucocorticoids in vitro (Sandri et al. 2004). Because FOXO, but not atrogin-1, overexpression is sufficient to cause muscle atrophy, it is thought that FOXO transcription factors activate a variety of genes, in addition to atrogin-1, that leads to atrophy. Taken together, these data indicate that increased expression of FOXO by glucocorticoids activates a gene transcriptional program responsible for triggering muscle atrophy. Among the genes most strongly induced in microarray analyses of muscle 
atrophy due to a variety of wasting diseases are several genes (atrogin-1, MuRF-1, cathepsin L, PDK4, p21, Gadd45, and 4E-BP1) controlled by the FOXO transcription factors (Jagoe et al. 2002, Komamura et al. 2003, Lecker et al. 2004, Almon et al. 2007). The establishment of an active transcriptional program necessary for the induction of muscle atrophy has thus challenged the view that atrophy is a passive adaptation of the muscle to a lack of anabolic stimuli. All these observations support the role of FOXO in muscle atrophy induced by glucocorticoids but there is not yet direct in vivo evidence for the requirement of FOXO in this muscle atrophy model (Fig. 2).

\section{$m T O R$}

The inhibition of protein synthesis by glucocorticoids mainly results from the inhibition of $m T O R$, the kinase responsible for the phosphorylation of 4E-BP1 and S6K1. Repression of mTOR signaling results in a reduction in the initiation phase of mRNA translation with downregulation of protein synthesis. Recent studies indicate that the repression of
mTOR signaling in response to glucocorticoids is the result of enhanced transcription of REDD1, a repressor of mTOR signaling (Wang et al. 2006). Through an as yet unidentified mechanism, REDD1 represses mTOR function, leading to decreased phosphorylation of both 4E-BP1 and S6K1. Recent evidence suggest that mTOR signaling could also be inhibited directly by FOXO (Southgate et al. 2007). Whereas the effects of glucocorticoids on protein synthesis have been explained at the molecular level, comparatively little is known about how these hormones alter anabolic gene expression. Recent studies identified ATF-4 as an anabolic transcription factor that is repressed by glucocorticoids (Adams 2007). ATF-4 has been shown to be required for the activation of a genetic program for the cellular uptake of essential amino acids and the synthesis of non-essential amino acids and aminoacyl-t-RNAs. This observation suggests that glucocorticoids inhibit protein synthesis at least partially by downregulating ATF-4, which could limit intracellular amino acid availability. It is interesting to note that insulin, an anabolic hormone, has been shown to induce ATF-4 transcription, even in the presence of glucocorticoids (Fig. 1).

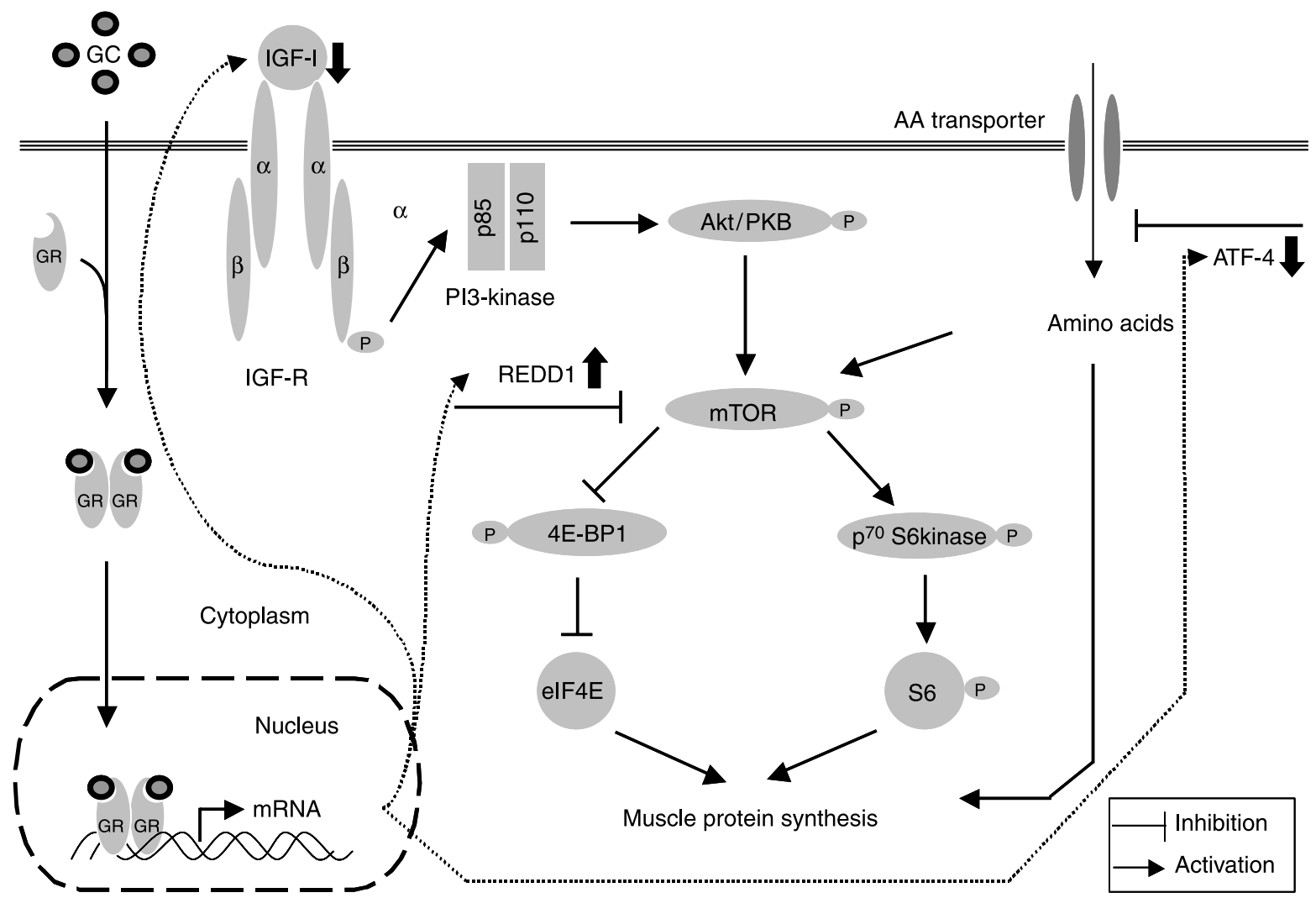

Figure 1 Alterations in protein synthesis signaling pathway induced by glucocorticoids. Inhibitory effects on protein synthesis results from different mechanisms. First, glucocorticoids (GC) impair protein synthesis by inhibiting the transport of amino acids into the muscle. Secondly, glucocorticoids inhibit the stimulatory action of insulin, IGF-I, and amino acids on elF4E-binding protein 1 (4E-BP1) and the ribosomal protein S6 kinase 1 (S6K1) through mTOR activity repression. 


\section{$\operatorname{GSK} 3 \beta$}

A downstream target of IGF-I/Akt signaling, glycogen synthase kinase $3 \beta(G S K 3 \beta)$, which is phosphorylated and inhibited by Akt, could also be involved in the atrophic effect of glucocorticoids. GSK3 $\beta$ is known to suppress protein synthesis by inhibiting eukaryotic transcription factor 2B-dependent translation (Jefferson et al. 1999). Furthermore, not only is inhibition of GSK3 $\beta$ sufficient to cause myogenic differentiation (Van Der Velden et al. 2006) and muscle cell hypertrophy (Vyas et al. 2002) but also contributes to the hypertrophic effect of IGF-I on skeletal muscle cells (Vyas et al. 2002). More interestingly, inhibition of GSK3 $\beta$ by overexpression of a dominant negative GSK3 $\beta$ or pharmacologic inhibitors prevents the proteolysis and cell atrophy caused by glucocorticoids in vitro (Rommel et al. 2001, Evenson et al. 2005, Fang et al. 2005). The mechanism by which GSK3 $\beta$ inactivation inhibits muscle protein degradation caused by glucocorticoids is not known. However, the observation that inhibition of protein degradation by GSK3 $\beta$ inhibitors is associated with the blockade of the upregulation of atrogin-1 and MuRF-1 gene expression suggests that this reduction in muscle proteolysis is mediated at least in part by inhibiting the UPS (Evenson et al. 2005). Although the role of GSK3 $\beta$ in muscle atrophy induced by glucocorticoids has not yet been demonstrated in vivo, the anti-catabolic effect of GSK3 $\beta$ inhibitors suggests that GSK3 $\beta$ may become an important target to inhibit muscle wasting in the future (Fig. 2).

\section{p300-C/EBP $\beta$}

Finally, recent in vitro data suggest that glucocorticoidinduced muscle proteolysis is at least in part regulated by p300-histone acetyl transferase activity. Indeed, p300 protein levels and activity are increased, in a time- and dosedependent manner, in dexamethasone-treated myotubes (Yang et al. 2005). Additionally, dexamethasone increases protein-protein interaction between $\mathrm{p} 300$ and C/EBP $\beta$, which increases the transcription activity of $\mathrm{C} / \mathrm{EBP} \beta$ by acetylation (Yang et al. 2005). This interaction is particularly important since $\mathrm{C} / \mathrm{EBP} \beta$ may regulate multiple genes in the UPS pathway (Penner et al. 2002). Finally, treatment of myotubes with p300 small interfering RNA prevents the dexamethasone-induced increase in protein degradation, whereas overexpression of wild-type p300 potentiates the effect of dexamethasone on protein degradation (Yang et al. 2007). Taken together, these results point out the main role of p300 in muscle proteolysis induced by glucocorticoids.

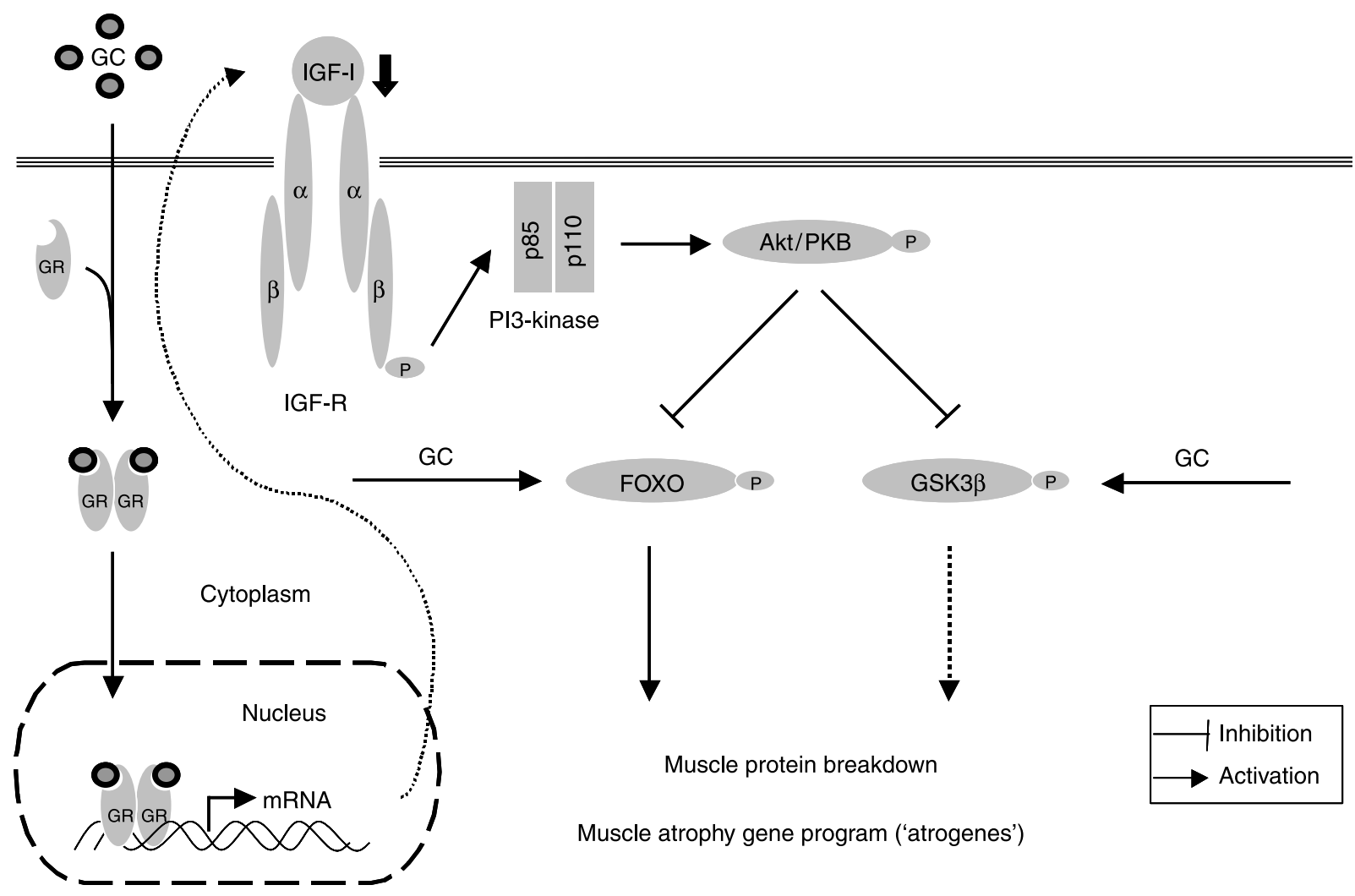

Figure 2 Alterations in protein breakdown signaling induced by glucocorticoids. Stimulatory effects on protein breakdown results from different mechanisms. First, glucocorticoids (GC) stimulate several proteolytic systems by activating transcription factor FOXO. Secondly, stimulation of GSK3 $\beta$ may also be involved in the stimulatory effects of glucocorticoids on protein breakdown. 
Seeing that several transcription factors involved in muscle wasting are regulated in part by acetylation (Mink et al. 1997, Schwartz et al. 2003, Chen \& Greene 2005, Perrot \& Rechler 2005), it appears crucial for the future to determine which proteins are acetylated in muscle atrophy and whether their acetylation controls glucocorticoid-induced muscle proteolysis.

\section{Role of local growth factors in glucocorticoid- induced muscle atrophy}

\section{$I G F-I$}

Glucocorticoids can also cause muscle atrophy by altering the production of growth factors that control locally the muscle mass development. Glucocorticoids inhibit the production by the muscle of IGF-I (Gayan-Ramirez et al. 1999), a growth factor that stimulates the development of muscle mass by increasing protein synthesis and myogenesis while decreasing proteolysis and apoptosis (Florini et al. 1996, Frost \& Lang 2003). For these reasons, decreased muscle IGF-I has been thought to play a key role in glucocorticoid-induced muscle atrophy. This hypothesis has recently been confirmed both in vitro and in vivo. First, by activating the $\mathrm{PI} 3 \mathrm{~K} / \mathrm{Akt} / \mathrm{mTOR}$ pathway and blocking nuclear translocation of the transcription factor FOXO, IGF-I downregulates the different proteolytic systems (lysosomal, proteasomal, and calpain dependent) and the expression of atrogenes such as atrogin-1, MuRF-1, cathepsin L induced by glucocorticoids (Dehoux et al. 2004, Latres et al. 2005, Li et al. 2005). Secondly, IGF-I suppresses the muscle cell atrophy caused by glucocorticoids in vitro (Li et al. 2004, Sacheck et al. 2004). Thirdly, systemic administration (Tomas et al. 1992, Tomas 1998, Kanda et al. 1999, Fournier et al. 2003) or local overexpression of IGF-I into skeletal muscle prevents glucocorticoid-induced muscle atrophy (Schakman et al. 2005). Taken together, these results indicate that IGF-I has a dominant effect, overriding glucocorticoids to turn off catabolism. In addition, they support the key role of decreased muscle IGF-I in the atrophy caused by glucocorticoids. Therefore, restoration of IGF-I may provide a strategy to reverse the catabolic effects of glucocorticoid excess (Fig. 3).

\section{Myostatin}

Glucocorticoids also stimulate the production by the muscle of myostatin (Mstn; Ma et al. 2001, 2003, Artaza et al. 2002), a growth factor that inhibits the muscle mass development by downregulating the proliferation, and differentiation of satellite cells (Thomas et al. 2000, McCroskery et al. 2003) and downregulating protein synthesis (Taylor et al. 2001, Welle et al. 2006). Recent evidence collected in vitro indicate that Mstn also causes muscle cell atrophy by reversing the IGF-I/PI3K/Akt hypertrophy pathway. Through inhibition of Akt phosphorylation, Mstn increases the levels of active

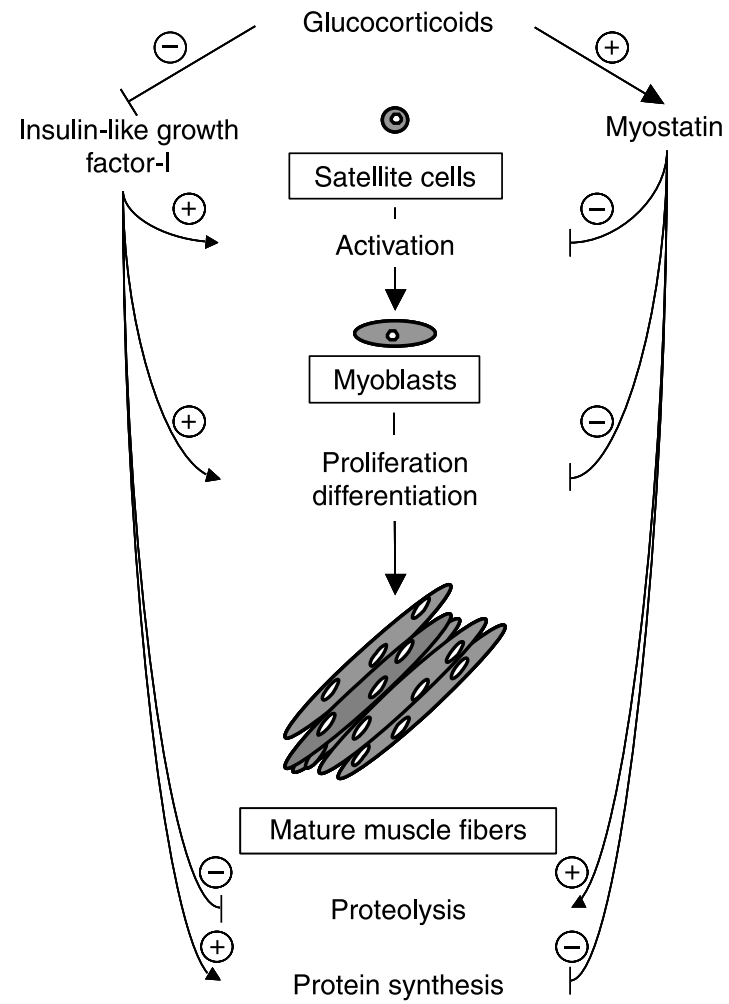

Figure 3 Local growth factors production plays a crucial role in glucocorticoid-induced muscle atrophy. Glucocorticoids can cause muscle atrophy by altering the muscle production of IGF-I and myostatin, two growth factors exhibiting opposite effects on muscle mass development. Decrease in IGF-I together with increase in myostatin both induced by glucocorticoids inhibit satellite cells activation as well as myoblast proliferation and differentiation. In mature muscle fibers, these growth factor changes cause downregulation of protein synthesis and stimulation of protein degradation.

FOXO, allowing increased expression of atrogenes (McFarlane et al. 2006). Furthermore, targeted disruption of Mstn gene expression in mice leads to dramatic increase in skeletal muscle mass due to fiber hyperplasia and/or hypertrophy (McPherron et al. 1997, Grobet et al. 2003). Finally, transgenic mice that express Mstn selectively in skeletal muscle have muscle atrophy (Reisz-Porszasz et al. 2003, Durieux et al. 2007).

For these reasons, increased muscle Mstn has been thought to play a key role in glucocorticoid-induced muscle atrophy. This hypothesis has recently been confirmed in vivo (Gilson et al. 2007) using a model of Mstn knockout (KO) mice. In contrast to wild-type mice, Mstn KO mice did not develop a reduction of muscle mass nor fiber cross-sectional area after glucocorticoid treatment. This observation indicates that Mstn is mandatory for the atrophic effects of glucocorticoids on muscle. The mechanism by which Mstn deletion prevents muscle atrophy caused by glucocorticoids is not known. However, the observation that prevention of muscle atrophy 
by Mstn deletion is associated with the blockade of the upregulation of atrogenes expression and proteosomal activity caused by glucocorticoids suggests that this protection of muscle mass results at least in part from the inhibition of the muscle proteolysis (Gilson et al. 2007). Taken together, these results suggest that increased Mstn contributes to the atrophic effects of glucocorticoids on skeletal muscle. Therefore, besides stimulating IGF-I, inhibition of Mstn may provide another strategy to reverse the catabolic effects of glucocorticoid excess (Fig. 3).

\section{Consequences of glucocorticoid-induced muscle atrophy}

Administration of high doses of glucocorticoids to animals causes not only decreased muscle mass but also muscle dysfunction characterized by reduced force and weakness (Shin et al. 2000). Also, in humans, a significant relationship between steroid usage and both peripheral and respiratory muscle strength has been reported in chronic pulmonary disease (Decramer et al. 1994) and cystic fibrosis (Barry \& Gallagher 2003). Peripheral muscle weakness has also been observed in patients with Cushing's syndrome, who exhibit high levels of endogenous glucocorticoids (Khaleeli et al. 1983, Mills et al. 1999). Therefore, glucocorticoid-induced atrophy may have significant clinical implications.

\section{Prevention of glucocorticoid-induced muscle atrophy}

\section{Growth factors}

As already presented, stimulation of IGF-I and inhibition of Mstn appear promising therapeutic tools to attenuate glucocorticoid-induced muscle atrophy (Kanda et al. 1999). Indeed, muscle IGF-I overexpression (Schakman et al. 2005) or myostatin deletion (Gilson et al. 2007) prevents glucocorticoid-induced muscle atrophy. Therefore, IGF-I stimulation or Mstn blockade might be beneficial for a variety of myopathies, such as the ones caused by high doses of glucocorticoids. Further experiments are needed to test this possibility.

\section{Branched chain amino acids (BCAAs)}

Provision of the BCAAs mimics the effect of a complete mixture of amino acids in stimulating protein synthesis in skeletal muscle (Kimball \& Jefferson 2006). Of the BCAAs, leucine appears to be the most important in stimulating protein synthesis (Lynch 2001). Therefore, it seems logical to propose to override the catabolic effects of glucocorticoids toward skeletal muscle by administration of BCAAs or leucine alone. However, the fact that glucocorticoids make the muscle protein synthesis resistant to exogenous BCAAs
(Liu et al. 2001, 2004, Kobayashi et al. 2006) and leucine (Rieu et al. 2004) does not support this hypothesis.

\section{Glutamine}

Glutamine is a conditional essential amino acid in catabolic states. Glutamine and alanyl-glutamine have been reported to prevent glucocorticoid-induced muscle atrophy (Hickson et al. 1995, 1996). However, attenuation of this muscle atrophy by glutamine infusion is not associated with changes in circulating IGF-I levels (Hickson et al. 1997). In contrast, administration of glutamine prevents glucocorticoid-induced Mstn expression, which suggests that glutamine may inhibit the atrophic effect of glucocorticoids on muscle strength through inhibiting Mstn (Salehian et al. 2006).

\section{Taurine}

Since ablation of taurine transporter gene results in susceptibility of exercise-induced weakness in vivo, it has been suggested that this transporter is essential for skeletal muscle function (Uozumi et al. 2006a). The role of taurine in the prevention of glucocorticoid-induced atrophy is suggested by two observations. First, taurine attenuates muscle cell atrophy caused by glucocorticoids in vitro (Uozumi et al. 2006b). Second, induction of taurine transporter prevents glucocorticoid-induced muscle cell atrophy (Uozumi et al. 2006a). Although attractive, the possibility for taurine to attenuate glucocorticoid effects on skeletal muscle warrants further investigations.

\section{Creatine}

Dietary supplementation with creatine monohydrate has been shown to attenuate the muscle weight loss and the atrophy of gastrocnemius type IIb fibers caused by glucocorticoids (Roy et al. 2002, Menezes et al. 2007). Furthermore, this protective effect was associated with an attenuation of the impairment of daily spontaneous running of animals receiving glucocorticoids (Campos et al. 2006). Although further work is required to determine the specific mechanisms underlying the effects of creatine on muscle, evidence collected in vitro suggests that creatine may act on muscle cells by increasing IGF-I expression (Deldicque et al. 2005).

\section{Clenbuterol}

Clenbuterol, a $\beta 2$-adrenergic receptor agonist used to increase muscle mass in cattle, has been tested to prevent glucocorticoid-induced muscle atrophy. Experiments have shown that clenbuterol is able to blunt at least partially the skeletal muscle atrophy caused by dexamethasone (Agbenyega \& Wareham 1992, Huang et al. 2000, Pellegrino et al. 2004). However, on diaphragm, attenuation of muscle atrophy was not associated with a protective effect on muscle dysfunction (Jiang et al. 1996). Evidence collected in vivo suggest that 
clenbuterol may exert its anti-catabolic effect on muscle by increasing IGF-I expression (Awede et al. 2002) while downregulating Mstn expression (Pearen et al. 2006).

\section{Androgens}

Administration of androgens, such as testosterone or nandrolone, a minimally aromatizable analog, prevents decreased muscle mass and strength caused by glucocorticoids in animals (Van Balkom et al. 1998) and humans (Crawford et al. 2003). Although the molecular mechanisms by which testosterone attenuates the effects of glucocorticoids are not fully elucidated, testosterone, like many other anabolic stimuli, appears to stimulate muscle IGF-I expression (Ferrando et al. 2002, Wu et al. 2007).

\section{Conclusion}

Glucocorticoids appear to play a crucial role in muscle atrophy observed in various pathological conditions. Decrease in protein synthesis and increase in protein degradation both contribute to this muscle atrophy. Different intracellular mediators, such as FOXO, GSK3 $\beta$, C/EBP $\beta$, p300, REDD1, and ATF4, are involved respectively in the muscle catabolic and anti-anabolic effects of glucocorticoids. IGF-I stimulation or myostatin blockade constitutes some of the most promising future therapeutical approaches to prevent muscle atrophy caused by glucocorticoids. Although many unanswered questions remain, understanding the cellular basis of the glucocorticoid-induced skeletal muscle atrophy will contribute to the rational development of therapeutic interventions and therefore minimize the debilitating effects of the muscle atrophic response to glucocorticoids.

\section{Acknowledgements}

The work of the authors was supported by grants from the Fund for Scientific Medical Research (Belgium), the National Fund for Scientific Research (Belgium), the Association Française contre les Myopathies (France), and the Fonds Spéciaux de Recherche (Université Catholique de Louvain, Belgium). The authors declare that there is no conflict of interest that would prejudice the impartiality of this scientific work.

\section{References}

Adams CM 2007 Role of the transcription factor ATF4 in the anabolic actions of insulin and the anti-anabolic actions of glucocorticoids. Journal of Biological Chemistry 282 16744-16753.

Agbenyega ET \& Wareham AC 1992 Effect of clenbuterol on skeletal muscle atrophy in mice induced by the glucocorticoid dexamethasone. Comparative Biochemistry and Physiology. Comparative Physiology 102 141-145.
Almon RR, DuBois DC, Yao Z, Hoffman EP, Ghimbovschi S \& Jusko WJ 2007 Microarray analysis of the temporal response of skeletal muscle to methylprednisolone: comparative analysis of two dosing regimens. Physiological Genomics 30 282-299.

Artaza JN, Bhasin S, Mallidis C, Taylor W, Ma K \& Gonzalez-Cadavid NF 2002 Endogenous expression and localization of myostatin and its relation to myosin heavy chain distribution in C2C12 skeletal muscle cells. Journal of Cellular Physiology 190 170-179.

Awede BL, Thissen JP \& Lebacq J 2002 Role of IGF-I and IGFBPs in the changes of mass and phenotype induced in rat soleus muscle by clenbuterol. American Journal of Physiology. Endocrinology and Metabolism 282 E31-E37.

Van Balkom RH, Dekhuijzen PN, Folgering HT, Veerkamp JH, Van Moerkerk HT, Fransen JA \& Van Herwaarden CL 1998 Anabolic steroids in part reverse glucocorticoid-induced alterations in rat diaphragm. Journal of Applied Physiology 84 1492-1499.

Barry SC \& Gallagher CG 2003 Corticosteroids and skeletal muscle function in cystic fibrosis. Journal of Applied Physiology 95 1379-1384.

Bodine SC, Latres E, Baumhueter S, Lai VKM, Nunez L, Clarke BA, Poueymirou WT, Panaro FJ, Na EQ, Dharmarajan K et al. 2001 Identification of ubiquitin ligases required for skeletal muscle atrophy. Science 294 1704-1708.

Campos AR, Serafini LN, Sobreira C, Menezes LG \& Martinez JA 2006 Creatine intake attenuates corticosteroid-induced impairment of voluntary running in hamsters. Applied Physiology, Nutrition, and Metabolism 31 490-494.

Chen LF \& Greene WC 2005 Assessing acetylation of NF- $\kappa$ B. Methods 36 368-375.

Combaret L, Adegoke OA, Bedard N, Baracos V, Attaix D \& Wing SS 2005 USP19 is a ubiquitin-specific protease regulated in rat skeletal muscle during catabolic states. American Journal of Physiology. Endocrinology and Metabolism 288 E693-E700.

Crawford BA, Liu PY, Kean MT, Bleasel JF \& Handelsman DJ 2003 Randomized placebo-controlled trial of androgen effects on muscle and bone in men requiring long-term systemic glucocorticoid treatment. Journal of Clinical Endocrinology and Metabolism 88 3167-3176.

Dardevet D, Sornet C, Savary I, Debras E, Patureau-Mirand P \& Grizard J 1998 Glucocorticoid effects on insulin- and IGF-I-regulated muscle protein metabolism during aging. Journal of Endocrinology 156 83-89.

Decramer M, Lacquet LM, Fagard R \& Rogiers P 1994 Corticosteroids contribute to muscle weakness in chronic airflow obstruction. American Journal of Respiratory and Critical Care Medicine 150 11-16.

Dehoux M, Van Beneden R, Pasko N, Lause P, Verniers J, Underwood L, Ketelslegers JM \& Thissen JP 2004 Role of the insulin-like growth factor I decline in the induction of atrogin-1/MAFbx during fasting and diabetes. Endocrinology 145 4806-4812.

Dekhuijzen PN, Gayan-Ramirez G, Bisschop A, de Bock V, Dom R \& Decramer M 1995 Corticosteroid treatment and nutritional deprivation cause a different pattern of atrophy in rat diaphragm. Journal of Applied Physiology 78 629-637.

Deldicque L, Louis M, Theisen D, Nielens H, Dehoux M, Thissen JP, Rennie MJ \& Francaux M 2005 Increased IGF mRNA in human skeletal muscle after creatine supplementation. Medicine and Science in Sports and Exercise 37 731-736.

Deval D, Mordier S, Obled C, Bechet D, Combaret L, Attaix D \& Ferrara M 2001 Identification of cathepsin L as a differentially expressed message associated with skeletal muscle wasting. Biochemical Journal $360143-150$.

Du J, Wang X, Miereles C, Bailey JL, Debigare R, Zheng B, Price SR \& Mitch WE 2004 Activation of caspase-3 is an initial step triggering accelerated muscle proteolysis in catabolic conditions. Journal of Clinical Investigation 113 115-123.

Durieux AC, Amirouche A, Banzet S, Koulmann N, Bonnefoy R, Pasdeloup M, Mouret C, Bigard X, Peinnequin A \& Freyssenet D 2007 Ectopic expression of myostatin induces atrophy of adult skeletal muscle by decreasing muscle gene expression. Endocrinology 148 3140-3147.

Evenson AR, Fareed MU, Menconi MJ, Mitchell JC \& Hasselgren PO 2005 GSK-3 $\beta$ inhibitors reduce protein degradation in muscles from septic rats and in dexamethasone-treated myotubes. International Journal of Biochemistry and Cell Biology 37 2226-2238. 
Fang CH, Li BG, James JH, King JK, Evenson AR, Warden GD \& Hasselgren PO 2005 Protein breakdown in muscle from burned rats is blocked by insulin-like growth factor $i$ and glycogen synthase kinase-3beta inhibitors. Endocrinology 146 3141-3149.

Ferrando AA, Sheffield-Moore M, Yeckel CW, Gilkison C, Jiang J, Achacosa A, Lieberman SA, Tipton K, Wolfe RR \& Urban RJ 2002 Testosterone administration to older men improves muscle function: molecular and physiological mechanisms. American Journal of Physiology. Endocrinology and Metabolism 282 E601-E607.

Fitts RH, Romatowski JG, Peters JR, Paddon-Jones D, Wolfe RR \& Ferrando AA 2007 The deleterious effects of bed rest on human skeletal muscle fibers are exacerbated by hypercortisolemia and ameliorated by dietary supplementation. American Journal of Physiology. Cell Physiology 293 C313-C320.

Florini JR, Ewton DZ \& Coolican SA 1996 Growth hormone and the insulin-like growth factor system in myogenesis. Endocrine Reviews 17 481-517.

Fournier M, Huang ZS, Li H, Da X, Cercek B \& Lewis MI 2003 Insulin-like growth factor-I prevents corticosteroid-induced diaphragm muscle atrophy in emphysematous hamsters. American Journal of Physiology. Regulatory, Integrative and Comparative Physiology 285 R34-R43.

Frost RA \& Lang CH 2003 Regulation of insulin-like growth factor-I in skeletal muscle and muscle cells. Minerva Endocrinologica 28 53-73.

Gayan-Ramirez G, Vanderhoydonc F, Verhoeven G \& Decramer M 1999 Acute treatment with corticosteroids decreases IGF-1 and IGF-2 expression in the rat diaphragm and gastrocnemius. American Journal of Respiratory and Critical Care Medicine 159 283-289.

Gilson H, Schakman O, Combaret L, Lause P, Grobet L, Attaix D, Ketelslegers JM \& Thissen JP 2007 Myostatin gene deletion prevents glucocorticoidinduced muscle atrophy. Endocrinology 148 452-460.

Goldberg AL, Tischler M, DeMartino G \& Griffin G 1980 Hormonal regulation of protein degradation and synthesis in skeletal muscle. Federation Proceedings 39 31-36.

Grobet L, Pirottin D, Farnir F, Poncelet D, Royo LJ, Brouwers B, Christians E, Desmecht D, Coignoul F, Kahn R et al. 2003 Modulating skeletal muscle mass by postnatal, muscle-specific inactivation of the myostatin gene. Genesis 35 227-238.

Hasselgren PO 1999 Glucocorticoids and muscle catabolism. Current Opinion in Clinical Nutrition and Metabolic Care 2 201-205.

Hasselgren PO \& Fischer JE 2001 Muscle cachexia: current concepts of intracellular mechanisms and molecular regulation. Annals of Surgery 233 9-17.

Hickson RC, Czerwinski SM \& Wegrzyn LE 1995 Glutamine prevents downregulation of myosin heavy chain synthesis and muscle atrophy from glucocorticoids. American Journal of Physiology 268 E730-E734.

Hickson RC, Wegrzyn LE, Osborne DF \& Karl IE 1996 Alanyl-glutamine prevents muscle atrophy and glutamine synthetase induction by glucocorticoids. American Journal of Physiology 271 R1165-R1172.

Hickson RC, Oehler DT, Byerly RJ \& Unterman TG 1997 Protective effect of glutamine from glucocorticoid-induced muscle atrophy occurs without alterations in circulating insulin-like growth factor (IGF)-I and IGFbinding protein levels. Proceedings of the Society for Experimental Biology and Medicine 216 65-71.

Huang ZF, Massey JB \& Via DP 2000 Differential regulation of cyclooxygenase-2 (COX-2) mRNA stability by interleukin-1 $\beta$ (IL-1 $\beta$ ) and tumor necrosis factor- $\alpha$ (TNF- $\alpha$ ) in human in vitro differentiated macrophages. Biochemical Pharmacology 59 187-194.

Imae M, Fu Z, Yoshida A, Noguchi T \& Kato H 2003 Nutritional and hormonal factors control the gene expression of FoxOs, the mammalian homologues of DAF-16. Journal of Molecular Endocrinology 30 253-262.

Jagoe RT, Redfern CP, Roberts RG, Gibson GJ \& Goodship TH 2002 Skeletal muscle mRNA levels for cathepsin B, but not components of the ubiquitin-proteasome pathway, are increased in patients with lung cancer referred for thoracotomy. Clinical Science 102 353-361.

Jefferson LS, Fabian JR \& Kimball SR 1999 Glycogen synthase kinase-3 is the predominant insulin-regulated eukaryotic initiation factor $2 \mathrm{~B}$ kinase in skeletal muscle. International Journal of Biochemistry and Cell Biology 31 191-200.
Jiang TX, Cairns A, Road JD \& Wilcox PG 1996 Effect of the beta-agonist clenbuterol on dexamethasone-induced diaphragm dysfunction in rabbits. American Journal of Respiratory and Critical Care Medicine 154 1778-1783.

Kamei Y, Miura S, Suzuki M, Kai Y, Mizukami J, Taniguchi T, Mochida K, Hata T, Matsuda J, Aburatani H et al. 2004 Skeletal muscle FOXO1 (FKHR) transgenic mice have less skeletal muscle mass, down-regulated Type I (slow twitch/red muscle) fiber genes, and impaired glycemic control. Journal of Biological Chemistry 279 41114-41123.

Kanda F, Takatani K, Okuda S, Matsushita T \& Chihara K 1999 Preventive effects of insulinlike growth factor-I on steroid- induced muscle atrophy. Muscle and Nerve 22 213-217.

Khaleeli AA, Edwards RH, Gohil K, McPhail G, Rennie MJ, Round J \& Ross EJ 1983 Corticosteroid myopathy: a clinical and pathological study. Clinical Endocrinology 18 155-166.

Kimball SR \& Jefferson LS 2006 Signaling pathways and molecular mechanisms through which branched-chain amino acids mediate translational control of protein synthesis. Journal of Nutrition 136 227S-231S.

Kobayashi H, Kato H, Hirabayashi Y, Murakami H \& Suzuki H 2006 Modulations of muscle protein metabolism by branched-chain amino acids in normal and muscle-atrophying rats. Journal of Nutrition 136 234S-236S.

Komamura K, Shirotani-Ikejima H, Tatsumi R, Tsujita-Kuroda Y, Kitakaze M, Miyatake K, Sunagawa K \& Miyata T 2003 Differential gene expression in the rat skeletal and heart muscle in glucocorticoid-induced myopathy: analysis by microarray. Cardiovascular Drugs and Therapy 17 303-310.

Kostyo JL \& Redmond AF 1966 Role of protein synthesis in the inhibitory action of adrenal steroid hormones on amino acid transport by muscle. Endocrinology 79 531-540.

Latres E, Amini AR, Amini AA, Griffiths J, Martin FJ, Wei Y, Lin HC, Yancopoulos GD \& Glass DJ 2005 Insulin-like growth factor-1 (IGF-1) inversely regulates atrophy-induced genes via the phosphatidylinositol 3-kinase/Akt/mammalian target of rapamycin (PI3K/Akt/mTOR) pathway. Journal of Biological Chemistry 280 2737-2744.

Lecker SH, Solomon V, Mitch WE \& Goldberg AL 1999 Muscle protein breakdown and the critical role of the ubiquitin- proteasome pathway in normal and disease states. Journal of Nutrition 129 227S-237S.

Lecker SH, Jagoe RT, Gilbert A, Gomes M, Baracos V, Bailey J, Price SR, Mitch WE \& Goldberg AL 2004 Multiple types of skeletal muscle atrophy involve a common program of changes in gene expression. FASEB Journal 18 39-51.

Li BG, Hasselgren PO, Fang CH \& Warden GD 2004 Insulin-like growth factor-I blocks dexamethasone-induced protein degradation in cultured myotubes by inhibiting multiple proteolytic pathways: 2002 ABA paper. Journal of Burn Care and Rehabilitation 25 112-118.

Li ZF, Shelton GD \& Engvall E 2005 Elimination of myostatin does not combat muscular dystrophy in dy mice but increases postnatal lethality. American Journal of Pathology 166 491-497.

Liu ZQ, Jahn LA, Long W, Fryburg DA, Wei LP \& Barrett EJ 2001 Branched chain amino acids activate messenger ribonucleic acid translation regulatory proteins in human skeletal muscle, and glucocorticoids blunt this action. Journal of Clinical Endocrinology and Metabolism 86 2136-2143.

Liu Z, Li G, Kimball SR, Jahn LA \& Barrett EJ 2004 Glucocorticoids modulate amino acid-induced translation initiation in human skeletal muscle. American Journal of Physiology. Endocrinology and Metabolism 287 E275-E281.

Lofberg E, Gutierrez A, Wernerman J, Anderstam B, Mitch WE, Price SR, Bergstrom J \& Alvestrand A 2002 Effects of high doses of glucocorticoids on free amino acids, ribosomes and protein turnover in human muscle. European Journal of Clinical Investigation 32 345-353.

Lynch CJ 2001 Role of leucine in the regulation of mTOR by amino acids: revelations from structure-activity studies. Journal of Nutrition $\mathbf{1 3 1}$ 861S-865S.

Ma K, Mallidis C, Artaza J, Taylor W, Gonzalez-Cadavid N \& Bhasin S 2001 Characterization of $5^{\prime}$-regulatory region of human myostatin gene: regulation by dexamethasone in vitro. American Journal of Physiology. Endocrinology and Metabolism 281 E1128-E1136. 
Ma K, Mallidis C, Bhasin S, Mahabadi V, Artaza J, Gonzalez-Cadavid N, Arias J \& Salehian B 2003 Glucocorticoid-induced skeletal muscle atrophy is associated with upregulation of myostatin gene expression. American Journal of Physiology. Endocrinology and Metabolism 285 E363-E371.

McCroskery S, Thomas M, Maxwell L, Sharma M \& Kambadur R 2003 Myostatin negatively regulates satellite cell activation and self-renewal. Journal of Cell Biology 162 1135-1147.

McFarlane C, Plummer E, Thomas M, Hennebry A, Ashby M, Ling N, Smith H, Sharma M \& Kambadur R 2006 Myostatin induces cachexia by activating the ubiquitin proteolytic system through an NF- $\mathrm{BB}$-independent, FoxO1-dependent mechanism. Journal of Cellular Physiology 209 501-514.

McPherron AC, Lawler AM \& Lee SJ 1997 Regulation of skeletal muscle mass in mice by a new TGF-beta superfamily member. Nature 387 83-90.

Menezes LG, Sobreira C, Neder L, Rodrigues-Junior AL \& Martinez JA 2007 Creatine supplementation attenuates corticosteroid-induced muscle wasting and impairment of exercise performance in rats. Journal of Applied Physiology 102 698-703.

Mills GH, Kyroussis D, Jenkins P, Hamnegard CH, Polkey MI, Wass J, Besser GM, Moxham J \& Green M 1999 Respiratory muscle strength in Cushing's syndrome. American Journal of Respiratory and Critical Care Medicine 160 1762-1765.

Mink S, Haenig B \& Klempnauer KH 1997 Interaction and functional collaboration of p300 and C/EBPbeta. Molecular and Cellular Biology 17 6609-6617.

Mitch WE \& Goldberg AL 1996 Mechanisms of muscle wasting. The role of the ubiquitin- proteasome pathway. New England Journal of Medicine 335 1897-1905.

te Pas MF, De Jong PR \& Verburg FJ 2000 Glucocorticoid inhibition of C2C12 proliferation rate and differentiation capacity in relation to mRNA levels of the MRF gene family. Molecular Biology Reports 27 87-98.

Pearen MA, Ryall JG, Maxwell MA, Ohkura N, Lynch GS \& Muscat GE 2006 The orphan nuclear receptor, NOR-1, is a target of $\beta$-adrenergic signaling in skeletal muscle. Endocrinology 147 5217-5227.

Pellegrino MA, D'Antona G, Bortolotto S, Boschi F, Pastoris O, Bottinelli R, Polla B \& Reggiani C 2004 Clenbuterol antagonizes glucocorticoidinduced atrophy and fibre type transformation in mice. Experimental Physiology 89 89-100.

Penner G, Gang G, Sun XY, Wray C \& Hasselgren PO 2002 C/EBP DNAbinding activity is upregulated by a glucocorticoid-dependent mechanism in septic muscle. American Journal of Physiology. Regulatory, Integrative and Comparative Physiology 282 R439-R444.

Perrot V \& Rechler MM 2005 The coactivator p300 directly acetylates the forkhead transcription factor Foxo1 and stimulates Foxo1-induced transcription. Molecular Endocrinology 19 2283-2298.

Reisz-Porszasz S, Bhasin S, Artaza JN, Shen R, Sinha-Hikim I, Hogue A, Fielder TJ \& Gonzalez-Cadavid NF 2003 Lower skeletal muscle mass in male transgenic mice with muscle-specific overexpression of myostatin. American Journal of Physiology. Endocrinology and Metabolism 285 E876-E888.

Rieu I, Sornet C, Grizard J \& Dardevet D 2004 Glucocorticoid excess induces a prolonged leucine resistance on muscle protein synthesis in old rats. Experimental Gerontology 39 1315-1321.

Rommel C, Bodine SC, Clarke BA, Rossman R, Nunez L, Stitt TN, Yancopoulos GD \& Glass DJ 2001 Mediation of IGF-1-induced skeletal myotube hypertrophy by PI(3)K/Akt/mTOR and PI(3)K/Akt/GSK3 pathways. Nature Cell Biology 3 1009-1013.

Roy BD, Bourgeois JM, Mahoney DJ \& Tarnopolsky MA 2002 Dietary supplementation with creatine monohydrate prevents corticosteroidinduced attenuation of growth in young rats. Canadian Journal of Physiology and Pharmacology 80 1008-1014.

Sacheck JM, Ohtsuka A, McLary SC \& Goldberg AL 2004 IGF-I stimulates muscle growth by suppressing protein breakdown and expression of atrophy-related ubiquitin ligases, atrogin-1 and MuRF1. American Journal of Physiology. Endocrinology and Metabolism 287 E591-E601.

Salehian B, Mahabadi V, Bilas J, Taylor WE \& Ma K 2006 The effect of glutamine on prevention of glucocorticoid-induced skeletal muscle atrophy is associated with myostatin suppression. Metabolism 55 1239-1247.
Sandri M, Sandri C, Gilbert A, Skurk C, Calabria E, Picard A, Walsh K, Schiaffino S, Lecker SH \& Goldberg AL 2004 Foxo transcription factors induce the atrophy-related ubiquitin ligase atrogin-1 and cause skeletal muscle atrophy. Cell 117 399-412.

Schakman O, Gilson H, de C V, Lause P, Verniers J, Havaux X, Ketelslegers JM \& Thissen JP 2005 Insulin-like growth factor-I gene transfer by electroporation prevents skeletal muscle atrophy in glucocorticoid-treated rats. Endocrinology 146 1789-1797.

Schwartz C, Beck K, Mink S, Schmolke M, Budde B, Wenning D \& Klempnauer KH 2003 Recruitment of $\mathrm{p} 300$ by C/EBPbeta triggers phosphorylation of $\mathrm{p} 300$ and modulates coactivator activity. EMBO Journal 22 882-892.

Shah OJ, Kimball SR \& Jefferson LS 2000a Acute attenuation of translation initiation and protein synthesis by glucocorticoids in skeletal muscle. American Journal of Physiology. Endocrinology and Metabolism 278 E76-E82.

Shah OJ, Kimball SR \& Jefferson LS $2000 b$ Among translational effectors, p70S6k is uniquely sensitive to inhibition by glucocorticoids. Biochemical Journal 347 389-397.

Shin YS, Fink H, Khiroya R, Ibebunjo C \& Martyn J 2000 Prednisoloneinduced muscle dysfunction is caused more by atrophy than by altered acetylcholine receptor expression. Anesthesia and Analgesia 91 322-328.

Southgate RJ, Neill B, Prelovsek O, El Osta A, Kamei Y, Miura S, Ezaki O, McLoughlin TJ, Zhang W, Unterman TG et al. 2007 FOXO1 regulates the expression of 4E-BP1 and inhibits mTOR signaling in mammalian skeletal muscle. Journal of Biological Chemistry 282 21176-21186.

Taylor WE, Bhasin S, Artaza J, Byhower F, Azam M, Willard DH Jr, Kull FC Jr \& Gonzalez-Cadavid N 2001 Myostatin inhibits cell proliferation and protein synthesis in $\mathrm{C}_{2} \mathrm{C}_{12}$ muscle cells. American Journal of Physiology. Endocrinology and Metabolism 280 E221-E228.

Thomas M, Langley B, Berry C, Sharma M, Kirk S, Bass J \& Kambadur R 2000 Myostatin, a negative regulator of muscle growth, functions by inhibiting myoblast proliferation. Journal of Biological Chemistry 275 40235-40243.

Tiao G, Fagan J, Roegner V, Lieberman M, Wang JJ, Fischer JE \& Hasselgren PO 1996 Energy-ubiquitin-dependent muscle proteolysis during sepsis in rats is regulated by glucocorticoids. Journal of Clinical Investigation $\mathbf{9 7}$ 339-348.

Tischler ME 1994 Effect of the antiglucocorticoid RU38486 on protein metabolism in unweighted soleus muscle. Metabolism 43 1451-1455.

Tomas FM 1998 The anti-catabolic efficacy of insulin-like growth factor-I is enhanced by its early administration to rats receiving dexamethasone. Journal of Endocrinology 157 89-97.

Tomas FM, Munro HN \& Young VR 1979 Effect of glucocorticoid administration on the rate of muscle protein breakdown in vivo in rats, as measured by urinary excretion of $\mathrm{N}$ tau-methylhistidine. Biochemical Journal 178 139-146.

Tomas FM, Knowles SE, Owens PC, Chandler CS, Francis GL, Read LC \& Ballard FJ 1992 Insulin-like growth factor-I (IGF-I) and especially IGF-I variants are anabolic in dexamethasone-treated rats. Biochemical Journal 282 91-97.

Uozumi Y, Ito T, Hoshino Y, Mohri T, Maeda M, Takahashi K, Fujio Y \& Azuma J 2006a Myogenic differentiation induces taurine transporter in association with taurine-mediated cytoprotection in skeletal muscles. Biochemical Journal 394 699-706.

Uozumi Y, Ito T, Takahashi K, Matsuda T, Mohri T, Kimura Y, Fujio Y \& Azuma J 2006b Myogenic induction of taurine transporter prevents dexamethasone-induced muscle atrophy. Advances in Experimental Medicine and Biology 583 265-270.

Van Der Velden JL, Langen RC, Kelders MC, Wouters EF, Janssen-Heininger YM \& Schols AM 2006 Inhibition of glycogen synthase kinase- $3 \beta$ activity is sufficient to stimulate myogenic differentiation. American Journal of Physiology. Cell Physiology 290 C453-C462.

Vyas DR, Spangenburg EE, Abraha TW, Childs TE \& Booth FW 2002 GSK$3 \beta$ negatively regulates skeletal myotube hypertrophy. American Journal of Physiology. Cell Physiology 283 C545-C551. 
Wang H, Kubica N, Ellisen LW, Jefferson LS \& Kimball SR 2006 Dexamethasone represses signaling through the mammalian target of rapamycin in muscle cells by enhancing expression of REDD1. Journal of Biological Chemistry 281 39128-39134.

Welle S, Bhatt K \& Pinkert CA 2006 Myofibrillar protein synthesis in myostatin-deficient mice. American Journal of Physiology. Endocrinology and Metabolism 290 E409-E415.

Wu Y, Zhao W, Zhao J, Pan J, Wu Q, Zhang Y, Bauman WA \& Cardozo CP 2007 Identification of androgen response elements in the insulin-like growth factor I upstream promoter. Endocrinology 148 2984-2993.

Yang H, Menconi MJ, Wei W, Petkova V \& Hasselgren PO 2005 Dexamethasone upregulates the expression of the nuclear cofactor p300 and its interaction with $\mathrm{C} / \mathrm{EBPbeta}$ in cultured myotubes. Journal of Cellula Biochemistry 94 1058-1067.
Yang H, Wei W, Menconi M \& Hasselgren PO 2007 Dexamethasoneinduced protein degradation in cultured myotubes is p300/HAT dependent. American Journal of Physiology. Regulatory, Integrative and Comparative Physiology 292 R337-R344.

Zamir O, Hasselgren PO, von Allmen D \& Fischer JE 1991 The effect of interleukin-1 alpha and the glucocorticoid receptor blocker RU 38486 on total and myofibrillar protein breakdown in skeletal muscle. Journal of Surgical Research 50 579-583.

Received in final form 28 January 2008

Accepted 31 January 2008

Made available online as an Accepted Preprint 31 January 2008 